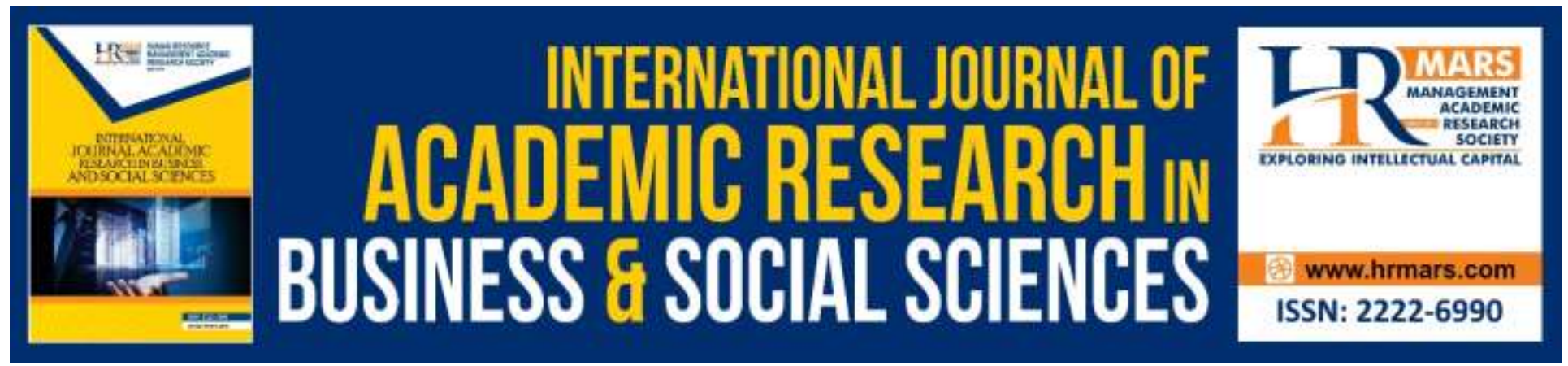

\title{
Antecedents of Employer's Compliance with Labour Standards: A Conceptual Framework
}

\author{
Nur Afeza Jaafar, Siti Noormi Alias, Zoharah Omar
}

To Link this Article: http://dx.doi.org/10.6007/IJARBSS/v9-i10/6520

DOI:10.6007/IJARBSS/v9-i10/6520

Received: 10 Aug 2019, Revised: 10 Sept 2019, Accepted: 30 Sept 2019

Published Online: 24 Oct 2019

In-Text Citation: (Jaafar, Alias, \& Omar, 2019)

To Cite this Article: Jaafar, N. A., Alias, S. N., Omar, Z. (2019). Antecedents of Employer's Compliance with Labour Standards: A Conceptual Framework. International Journal of Academic Research in Business and Social Sciences, 9(10), 356-372.

Copyright: (C) 2019 The Author(s)

Published by Human Resource Management Academic Research Society (www.hrmars.com)

This article is published under the Creative Commons Attribution (CC BY 4.0) license. Anyone may reproduce, distribute, translate and create derivative works of this article (for both commercial and non-commercial purposes), subject to full attribution to the original publication and authors. The full terms of this license may be seen

at: http://creativecommons.org/licences/by/4.0/legalcode

Vol. 9, No. 10, 2019, Pg. 356 - 372

http://hrmars.com/index.php/pages/detail/IJARBSS

JOURNAL HOMEPAGE

Full Terms \& Conditions of access and use can be found at http://hrmars.com/index.php/pages/detail/publication-ethics 


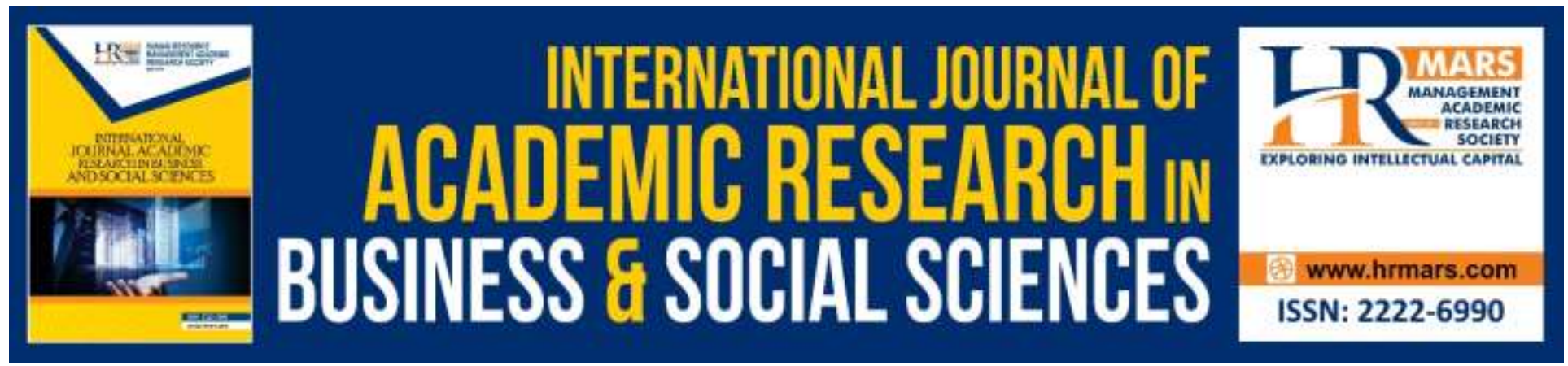

\title{
Antecedents of Employer's Compliance with Labour Standards: A Conceptual Framework
}

\author{
Nur Afeza Jaafar, Siti Noormi Alias, Zoharah Omar \\ Faculty of Educational Studies, Universiti Putra Malaysia
}

\begin{abstract}
Compliance with labour standards must be an ultimate goal for every firm to enhance their productivity, performance and efficiency. This paper aims to propose a conceptual model of the employer's compliance with labour standards. The paper goes to analyse factors that play a role in compliance behaviour. The factors were outlined in this paper by adopting Lindenberg's Goal Framing Theory (GFT) and the Option-Generation Framework Theory. The methodology used in this study is based on a systematic literature review of past studies from the year 2015 until 2019. A compilation of the previous studies were collected from several searching engines, for example, Emerald Insight, JSTOR, and Springer Link. Several keywords such as 'factor influencing/firm compliance/compliance behaviour/labour legislation' were used and only an empirical paper from social sciences discipline were selected as inclusion criteria. The studies then, were analysed and discussed in the context of factors that influence employer's compliance. The findings on the paper will include the type of factors that play a role in compliance behaviour and which factor appears to be the most influential to employers including trends and changing in compliance behaviour in the past recent years. It has to be noted here that it is important for employers to understand the importance of law compliance as it may be the factor that leads to productivity and company's financial stability. It also will benefit the policymaker in encouraging employer towards labour standards practices, restructuring policies in labour standard and understanding the compliance trends of employers in the future.
\end{abstract}

Keywords: Employers' Compliance, Labour Standards, Compliance Behaviour, Goal Framing Theory

\section{Introduction}

\section{Labour Standards Compliance}

Historically, a labour law was only representing a relationship between a master and a servant, in which a servant agreed to obey orders and to be under control of the master. A servant fully depends on the master's direction and methods of completing the task. In return, the master agreed to pay the servant a wage and provide a minimum protection for the servant (Tomlins, 2013). As the law developed, the master and servant relationship was replaced by the employer 
and employee relationship in the modern form (Francesco, Oppenheimer, Donnelly, \& Ginsburg, 2015). Islam \& Rahman (2015), view the modern labor law as a bridge between employeremployees that ensure a win-win employment relationships executed by a formal contract. These rules are primarily designed to keep employees safe and to ensure they are treated fairly. In Malaysia, labor law is also known as "employment law" concerns the inequality of bargaining power between employers and employees that governs the rights and duties between both.

The pattern of noncompliance issue seems to be a worldwide trend as it contains the similar legal issues. Studies conducted in many countries have consistently shown that labour standard's compliance in the food and beverage (F\&B) industry is precisely low compared to the other industries. Food services have a high rank of labour standards violation and also accounted for low number of employees employed in the industry (Weil, 2011).

In the United States alone, a low wage worker was striking and picketing demanding of RM58.67 an hour and predictable work schedules at a fast-food outlet in major cities across the country since 2012 (Fisk \& Rutter, 2015). Meanwhile, Kristen, Banuelos, \& Urban (2015), reported that low-wage worker who were harassed in the workplace had to face a difficulty and hardship when seeking justice and most of them did not know where to ask for help (International Labour Organization, 2016; Su, 2016). Not only poor working condition and less understanding about their rights on employment, but Su (2016) also reported that wage theft occurs where a worker is paid less than earned, and it takes many forms. For example, In California, RM 70.41 million was stolen from over 600 workers in ten buffet restaurants. In another case, a San Diego restaurant refuse to pay a minimum wages to the college students who also a worker in that restaurant. When the worker bring up the issue and consequently, they were fired.

One of the biggest mistake employers did is underestimating the importance of employment law and compliance. Business owner assumed that compliance is only about staying out of legal trouble with the government and avoidance of fines or legal action. Sometimes they disregard or give less attention to regulatory changes and basic regulation stated in the law. However, a good employer supposedly does not take for granted the legal side of manpower management. The legal compliance must come first for obvious reasons. Obeying the rules through overall business strategy may prevent future legal violations, scandals that will cost companies millions in lawsuits and government penalties (Peterson, 2013). According to previous studies, higher compliance on labour standard are proven to improved employees' performance (Artuso \& McLarney, 2015), give an employment opportunities (Piore \& Skinner, 2015), increase in employees' job commitment (Raziq \& Maulabakhsh, 2015), work wellbeing, and productivity (Foldspang et al., 2014).

The compliance of labour standards gives benefits to companies in the long run. It ensures the business is running well as it allows organizational responses to be faster and more organized. It also leaves less time for the legal problems to cause substantial damages (Peterson, 2013). All this supporting literature has clearly shown that it is clearly important for business organizations to ensure every action taken regarding employment is in line with the labour standards requirement.

\section{Theorizing Compliance with Labour Standards}

There are several theories used to understand compliance behaviour in literature such as the Theory of Reasoned Action (TRA), Goal Framing Theory (GFT), and Compliance Theory. They 
are being used in various field like education (Chakraborty, Singh, \& Roy, 2017) safety, medical, environment (Lindenberg \& Steg, 2013) and tax (Al, Saad, \& Haniffa, 2014; Fauziati, Minovia, Muslim, \& R. Nasrah, 2016). In this study, Lindenberg's Goal-Framing Theory and the OptionGeneration Framework by Kalis, Kaiser, \& Mojzisch (2013) was adopted to explore the employer behavioural on labour standards compliance.

\section{Lindenberg's Goal Framing Theory (GFT)}

In general, GFT elaborates the relationship between supervisor and subordinate in the organization. According to this theory, a supervisor has the power to control his subordinate on how to make a job done using three broad categories; the hedonic goal, the gain goal and the normative goal (Lindenberg \& Steg, 2007).

\section{Hedonic Goal}

Studies on regulatory enforcement in compliance level are much more related to certain behaviours such as emotional responses especially anger, fear, guilt, and shame. There are many reasons why people obey laws. For some, compliance is motivated by a sense of fear if they caught by breaking the law (Murphy, Bradford, \& Jackson, 2016). The hedonic goal may be seen in various forms. The role of fear can work as evidence in strong hedonic goal. It works as a threat that puts people in a hedonic goal-frame where disposing of one's fear is the main motivation for compliance. Guilt and shame are also part of hedonic aspects (Etienne, 2011). Those who are afraid of any prosecution act towards them will more encourage to comply with the law. Same goes to those who keep their high reputation will much easier to follow the rules.

\section{Gain Goal}

Gain goal plays an important role in societies where it contributes to sustaining gain goalframes for the performance of multifarious tasks. Various studies suggest that normative goal frames are often easily and rapidly displaced by gain signals embodied in, for instance, monetary rewards, while the reverse displacing a gain goal-frame with the normative goal (Chakraborty et al., 2017; Nielsen \& Parker, 2012). Gain goal focus on others intention towards the prospect of a reward or profit in the form of money, power, influence etc. to improve his situation in the long run (Arpita Chakraborty, Manvendra Pratap Singh, 2016). In general, people are more encouraged to conform if they are capable to do so in term of their financial status or the ability to direct others.

\section{Normative Goal}

The normative goal can be discovered in multiple acts of regulatory policy. Laws themselves bring people's attention to obey the law and hence contribute to strengthening normative goals. It can be summarized as "to act appropriately" or "to do the right thing." In other words, it refers as a motive to abide by social norms, understood as rules shared within a group and controlled by its members (Etienne, 2011). In other words, subjective norms are the general attitudes or judgments which are important and others have toward a specific behavior. For instance, when people around such family and friends demand us to obey the laws, the stronger compliance behavioral intention becomes (Kim \& Kim, 2017; Nielsen \& Parker, 2012).

\section{The Option-Generation Framework (TOGF)}

Theory of TOGF was adopt by Kalis et al. (2013) deals with the relation between knowledge and action. The theory explain about the idealized process of option generation, 
option selection, and action initiation and gives the background of the ideas that Kalis et al. (2008) have about degenerative processes in this area (Funke, 2017). This concept links knowledge and action in a special way: It makes a connection between options and actions. For instant, someone with knowledge will choose the action that will leads to its goal. They would not acting against their knowledge.

In overall, based on the GFT and TOGF it is quite common to differentiate between external and internal factor (Nielsen \& Parker, 2012). The external factor is a situation where someone is forced or being persuaded to do something because they are afraid of any punishment, sanction or penalties against them or because he or she wants to obtain some rewards in the society. The hedonic and normative goal is much related to the external factor which refers as a factor that influences the one's act. Meanwhile, an internal factor refers to the situation whereby people do something because they have consciousness and they are capable to do it without influence from others. An internal factor can be related to the gain goal or knowledge that they have which encourages people to behave in a specific way. Therefore, the four factors to consider that might contribute to the compliance of labour standards which is enforcement by government and social influence (external factor), knowledge and employer financial factor (internal factor) will be explored in this paper.

\section{Methodology}

This study is based on extensive reviews of past studies on employers' compliance with labour standards, covering local and international literature available through online databases. Three main database are used to manage the search of the target article including (1) Emerald Insight (EI), (2) JStor (JS) and (3) Springer Link (SL). The process of retrieving the right literature began with the selection of accurate keywords as suggested by (Cronin, Ryan, \& Coughlan, 2008). Suitable synonym was used when searched for an article such as 'factor influencing', 'firm compliance', 'compliance behaviour' and 'labour legislation'. This paper also limit the search to English-language literature.

The first step in the liquidation process is to exclude the duplicate articles using duplicate filter. They are then sorted and filtered by reading the title and abstract for each article in order to filter the isolate articles that no relevance with the subject. The last step consists of the text being read in detail to be analysed in this study. Three inclusion criteria were used to select the articles. First, the relevancy or age of the material. In this paper, only an article that directly related to the topic within five years old (2015-2019) is been considered. Second, articles and/or reports had to include quantitative or qualitative empirical information. The goal was to outline the extant empirically-based findings on the factors influencing employer's compliance field; thus, an articles that did not present original findings from data were excluded. Finally, documents had to focus on the factors contributed to the employer's compliance in law in any field of study.

A mix of keywords a group of keywords that contained all topics related to labour standards compliance used when search for the articles. During the search process, a book chapters, conference or report were excluded. Only an article needed and will be reviewed. The exact query text is shown at the top of Fig. 1. 
Query: "factor influencing", "firm compliance" OR "compliance behavior", "labor legislation" OR "labor standards" OR "employment regulation".
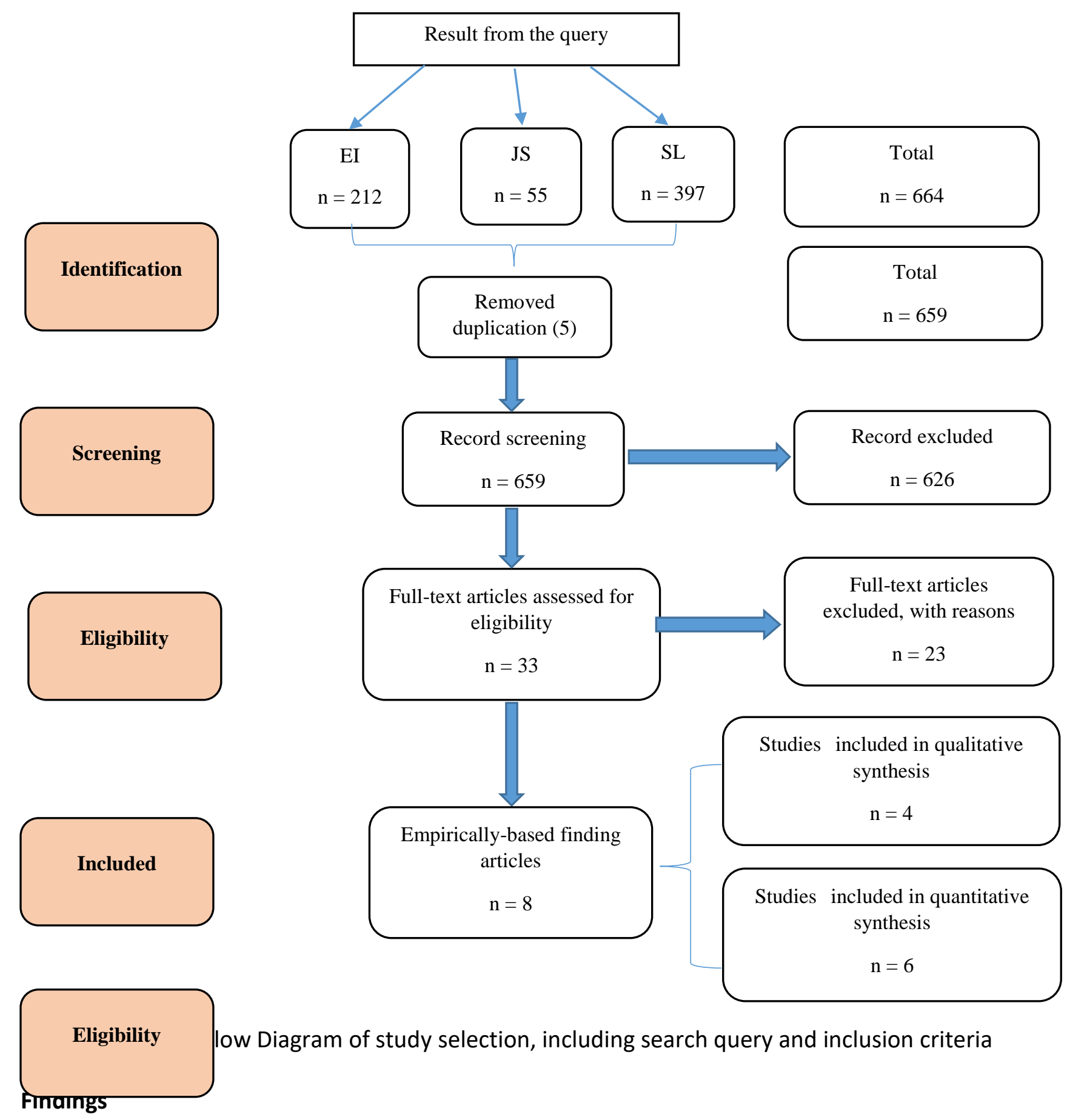

The initial query search resulted in 33 articles from 2015 to 2019: 13 from Springer Link database; 5 from JStor; and 15 from Emerald Insight. Those papers were read thoroughly for the 
primary purpose of finding out a general map for research on this emerging topic. The second iteration filtered the articles after a complete reading of the full text of the articles displayed, with the final 8 set included and 23 article were excluded from the list for some reason including the review and survey paper; unrelated topic and field; and focusing on other dimension of law compliance. Those 8 article were empirically studies where 4/8 in qualitative method, while 6/8 were using quantitative method.

\section{Factors Influencing Employers' Compliance Behaviour}

There are various publications and previous studies on factors contributing to compliance, which most of them highlighting on the influence of external (extrinsic) and internal (intrinsic) factors (i.e., (Islam \& Rahman, 2015; Murphy et al., 2016; Nielsen \& Parker, 2012; Shakeel, 2015; Voermans, 2015)). Those 8 article found using systematic literature review method also explain about factors contributed to the compliance. The factors listed in the articles then grouping into external and internal factors as shown below.

Table 1: Review articles in detail and grouping into subcategories

\begin{tabular}{|c|c|c|c|c|c|}
\hline No & Author & Year & Article Title & $\begin{array}{l}\text { Factors influencing } \\
\text { compliance }\end{array}$ & $\begin{array}{c}\text { External/ } \\
\text { Internal } \\
\text { Factor }\end{array}$ \\
\hline \multirow[t]{2}{*}{1.} & \multirow[t]{2}{*}{ Melissa Rorie } & \multirow[t]{2}{*}{2015} & \multirow[t]{2}{*}{$\begin{array}{l}\text { An integrated theory of } \\
\text { corporate environmental } \\
\text { compliance and } \\
\text { overcompliance }\end{array}$} & $\begin{array}{ll}\text { - } & \text { Legal } \\
\text { - } & \text { Social } \\
\text { - } & \text { Economic } \\
\text { - } & \text { Culture } \\
\end{array}$ & External \\
\hline & & & & - corporate policies & Internal \\
\hline \multirow[t]{2}{*}{2.} & \multirow{2}{*}{$\begin{array}{l}\text { Jonas } \\
\text { Winther, Line } \\
\text { Hillersdal }\end{array}$} & \multirow[t]{2}{*}{2019} & \multirow{2}{*}{$\begin{array}{l}\text { Balancing methodological } \\
\text { purity and social relevance: } \\
\text { monitoring participant } \\
\text { compliance in a behavioural } \\
R C T\end{array}$} & $\begin{array}{ll}\text { - } & \text { Practices } \\
\text { - } & \text { Technologies } \\
\end{array}$ & External \\
\hline & & & & - Knowledge & Internal \\
\hline 3. & $\begin{array}{l}\text { Richard M. } \\
\text { Locke, Hiram } \\
\text { Samel }\end{array}$ & 2018 & $\begin{array}{l}\text { Beyond the Workplace: } \\
\text { "Upstream" Business } \\
\text { Practices and Labor } \\
\text { Standards in the Global } \\
\text { Electronics Industry }\end{array}$ & $\begin{array}{ll}\text { - } & \text { work organization } \\
\text { - } & \text { working conditions }\end{array}$ & Internal \\
\hline \multirow[t]{2}{*}{4.} & \multirow[t]{2}{*}{$\begin{array}{l}\text { Mohammad } \\
\text { Nurunnabi }\end{array}$} & \multirow[t]{2}{*}{2018} & \multirow[t]{2}{*}{$\begin{array}{l}\text { Tax evasion and religiosity } \\
\text { in the Muslim world: the } \\
\text { significance of Shariah } \\
\text { regulation }\end{array}$} & 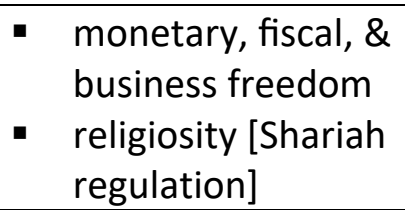 & Internal \\
\hline & & & & $\begin{array}{l}\text { - legal enforcement } \\
\text { - } \text { public sector } \\
\text { governance } \\
\text { - culture }\end{array}$ & External \\
\hline
\end{tabular}


INTERNATIONAL JOURNAL OF ACADEMIC RESEARCH IN BUSINESS AND SOCIAL SCIENCES

Vol. 9, No. 10, October, 2019, E-ISSN: 2222-6990 @ 2019 HRMARS

\begin{tabular}{|c|c|c|c|c|c|}
\hline 5. & $\begin{array}{l}\text { Helena } \\
\text { Sjögrén \& Pasi } \\
\text { Syrjä }\end{array}$ & 2015 & $\begin{array}{l}\text { Regulation compliance in } \\
\text { small Finnish companies }\end{array}$ & $\begin{array}{l}\text { - } \begin{array}{l}\text { trustful orientation } \\
\text { towards regulation }\end{array} \\
\text { - } \text { competition } \\
\text { advantage seeking } \\
\text { orientation } \\
\text { towards regulation } \\
\text { minimal compliant } \\
\text { orientation } \\
\text { towards regulation }\end{array}$ & Internal \\
\hline \multirow[t]{2}{*}{6.} & \multirow{2}{*}{$\begin{array}{l}\text { Gorrettie Kyeyune } \\
\text { Nakyeyune, Vena } \\
\text { ncio } \\
\text { Tauringana, Josep } \\
\text { h Mpeera } \\
\text { Ntayi \& Stephen } \\
\text { Korutaro } \\
\text { Nkundabanyanga }\end{array}$} & \multirow[t]{2}{*}{2016} & \multirow[t]{2}{*}{$\begin{array}{l}\text { Public finance regulatory } \\
\text { compliance among public } \\
\text { secondary schools }\end{array}$} & $\begin{array}{l}\text { - } \text { deterrence } \\
\text { - governing board } \\
\text { expertise }\end{array}$ & External \\
\hline & & & & 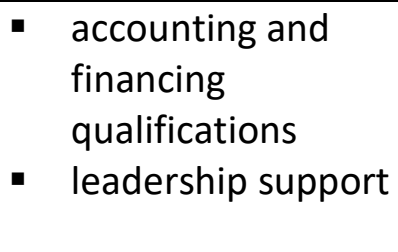 & Internal \\
\hline \multirow[t]{2}{*}{7.} & \multirow{2}{*}{$\begin{array}{l}\text { James Upstill- } \\
\text { Goddard, Jacqui } \\
\text { Glass, Andrew } \\
\text { Dainty \& Ian } \\
\text { Nicholson }\end{array}$} & \multirow[t]{2}{*}{2016} & \multirow[t]{2}{*}{$\begin{array}{l}\text { Implementing sustainability } \\
\text { in small and medium-sized } \\
\text { construction firms }\end{array}$} & $\begin{array}{l}\text { - Knowledge } \\
\text { - Experience }\end{array}$ & Internal \\
\hline & & & & - Activation triggers & External \\
\hline \multirow[t]{2}{*}{8.} & \multirow{2}{*}{$\begin{array}{l}\text { Chitra } \\
\text { Pandey \& Hema } \\
\text { Diwan }\end{array}$} & \multirow[t]{2}{*}{2018} & \multirow{2}{*}{$\begin{array}{l}\text { Integrated approach for } \\
\text { managing fertilizer } \\
\text { intensification linked } \\
\text { environmental issues }\end{array}$} & - social factors & External \\
\hline & & & & $\begin{array}{l}\text { - landsize } \\
\text { - } \text { knowledge }\end{array}$ & Internal \\
\hline
\end{tabular}

As shown on the table 1, the finding from those 8 articles resulted in mixed factors influencing compliance such as deterrence (Nakyeyune, Tauringana, Ntayi, \& Nkundabanyanga, 2016), knowledge and experience (Pandey \& Diwan, 2018), leadership (Nakyeyune et.al, 2016), legal (Nurunnabi, 2017; Rorie, 2015), working condition (Locke \& Samel, 2018), monetary freedom (Nurunnabi, 2017), corporate policies and culture (Nurunnabi, 2018: Rorie, 2015). It is clearly understand that most of the organization are difficult to comply with the regulation enforced and their number as a noncompliance are increasing (Sjögrén \& Syrjä, 2015). There are much factors contributed to the increasing figure, in most of the cases, the organization assume that lack or unclear of regulation (Sjögrén, 2015; Nurunnabi, 2018: Rorie, 2015) which have an impact on businesses as the strong factor contribute to their attitude towards regulation.

Nonetheless, on other scholars on regulation compliance proved that enforcement by government, social influence, knowledge and financial performance was a strong influencer towards regulation compliance in the organization. Those factors will be discuss further and grouping into external and internal factors, so that determinant factor of compliance will be understand clearly.

\section{External Factor}


External factors have a very important role in shaping one's decision to comply. It acts as a critical part of the development of opinion and attitude. One of the external factors is the enforcement factor. There are many forms of enforcement including inspection, notice of noncompliance, summons, penalties, and prosecution can be issued by labour officer to the noncompliance employer. However, enforcement on this study is much focus to the inspection by the government to the workplace. Most of the employer was not so happy when their company being visited by the labour officer. The employers assumed that an inspection was about to dig into their offence and must be triggered by a complaint made by their current or a former worker. In fact, many employer unaware they had a labour standards' problem until an inspection conducted into their premises (Shilpa, 2011). According to Weil (1996), the level of labour standards compliance will be higher when the number of inspection are higher and it's pressuring the business owner to comply with labour standards. Besides, studies from Nordic Country also show a positive outcome related to the frequency of labour inspection were proved to reduce risk factors related to the work organisation and interpersonal relationships such as violence, overload, harassment, threats and lack of recognition (Weissbrodt \& Giauque, 2017). According to Weissbrodt \& Giauque (2017) the intensity of inspection has influenced compliance. This relationship suggested that people comply with the law if the authority increases the inspection effort. But in most cases employer try to avoid their company from being inspected by a labour officer because they thought they were compliant, but actually, the employer was only aware that they are not following the rules and regulation correctly by going through an audit process by a labour officer (Islam \& Rahman, 2015).

Another external factor that influences compliance is the social influence. Social influence means the impact of significant or 'referent' who can lead to one imitating or learning from the behaviour of others along with authority pressures (Schwartz, 2016). If a company complies with the rules and regulations set by the government, it should affect its business partners to join the same practice too. Likewise, if one's employer does not completely comply with government regulation, he may also influence other employers in not following the regulation too (Hwang, Kim, Kim, \& Kim, 2017). Compliance is motivated by a normative concern such as assessing others who are important to him/her within their network that will influence the decision related to behaviour (Asselt, Osinga, \& Bremmers, 2016). Sometimes people unintentionally comply with the rules by adapting to their environment (Galander, Walgenbach, \& Rost, 2015). However, Lam \& Goo (2015) point out that, not all social influence necessarily favor compliance. It is usual to learning from other behavior even though it is unlawful to act as long it is falling below the acceptable social norms. Furthermore, some of the employers are comfortable to deal with their peers in a specific sector to get an information. They share the same opinion and thought on a highlighted issue that was specific into their network. Unfortunately, most of them too rely on the information given by their peers or informal network which they trust more rather than get an accurate information from the government body (Shilpa, 2011). Regrettably, if the wrong information is given, then it leads to the wrong labour standards practise by the employer. This means that an employer's compliance or noncompliance behavior is not only driven by their own consideration but also other's behavior on the same network.

Therefore, this study hypothesizes that,

H1: There is a relationship between enforcement by government and labour standards compliance by the employer 
H2: There is a relationship between social influence and labour standards compliance by the employer

\section{Internal Factor}

The internal factor is a critical factor that can influence compliance behaviour among employers. One of the important individual factors is knowledge. Compliance knowledge is defined as a personal judgement of personal skills and knowledge about fulfilling the requirements of the laws and regulations (Kim \& Kim, 2017). Hwang et al. (2017) revealed that education can reduce non-compliance, which eventually increases employer' compliance intention. Somehow, some legislation can be quite complicated, keep changing and also can vary between industries. That's why, compliance with specific laws such as labour standards often requires a high level of knowledge from the target group, which may be a barrier for compliance (Poudel, 2017). On the current employment situation, an employer might have incorrect information about labour law and they do not know how to interpret and use it. Therefore, they must be adequately prepared and informed about all provision and regulation under labour law and how to manage their employees' rights and protection since the early stages of their business. Rhodes \& Wray-Bliss (2013) suggested that companies may need to increase training for internal personnel and hire high-quality auditors for ensuring compliance. Those who understand the law better become aware of their obligation and will have a good working environment in their organization (Peterson, 2013). However, knowing a rule well does not automatically lead to a good compliance. In one of the tax study prove it otherwise which knowledge among taxpayer does not affect the decision to comply and implement the tax compliance (Fauziati et al., 2016). In some cases knowing a rule better also means that one knows better how to commit fraud or escape from the rules. Lack of knowledge, on the other hand, does not always lead to the violation of the rules (The Netherlands Ministry of Justice, 2004)

Besides knowledge, another internal factor that leads to employer compliance is the financial factor. Lack of money always is one of the argument issues when comes to labour standards compliance. For example when a Minimum Wage Order gazetted on the year 2013 and set up a minimum wage was not less than RM 1,000.00 per month, most of the companies give an excuse cannot comply the order yet have to spend for operational cost and capital to run a business. Some of them plan to reduce benefits to their workers for the survival of their business. Most of the employers at the early stage of their business are usually very concerned about their financial gains. They are likely to pursue and focus on their short-term wealth achievement and assuming that labour compliance will add cost to their organizations' operation (Qian, 2014). One of the studies in Bangladesh revealed that the employer get a huge benefit from the noncompliance especially in term of financial nature. Bangladesh's export-oriented textile industry was progressing high economic rates in the last decades and indicated the successful growth. The industry is making profit by putting aside their welfare and protection. Bangladesh offer a huge amount of workers that were willing to work for an extremely low wage was able to attract many foreign companies with its unprecedentedly low production costs (Wildgruber, 2013). However, Gonzalez (2015) indicated that finance was not a valid excuse for noncompliance. Even the highest-revenue companies showed a higher incidence of misconduct (Yeoh, 2014). The effect of noncompliance will increase a company's financial load instead when they have to deal with a court charge, higher penalties and repay any arrears which normally come out with an interest, etc. (Shilpa, 2011). A stronger labour protection will control risks in economic impact and reduce 
operating flexibility (Kono \& Barnes, 2010; Ni \& Zhu, 2018). It also could produce more efficient work practices from a highly motivated employee and contribute to improve the company's financial performances (Ng \& Said, 2015).

Based on the above argument, this study hypothesizes that, H3: There is a relationship between knowledge and labour standards compliance by the employer H4: There is a relationship between financial factor and labour standards compliance by the employer

Based on the above discussion, a conceptual model to show the relationships between the variables has been developed. Figure 2 illustrates a model showing the antecedents of employer's compliance with labour standards.

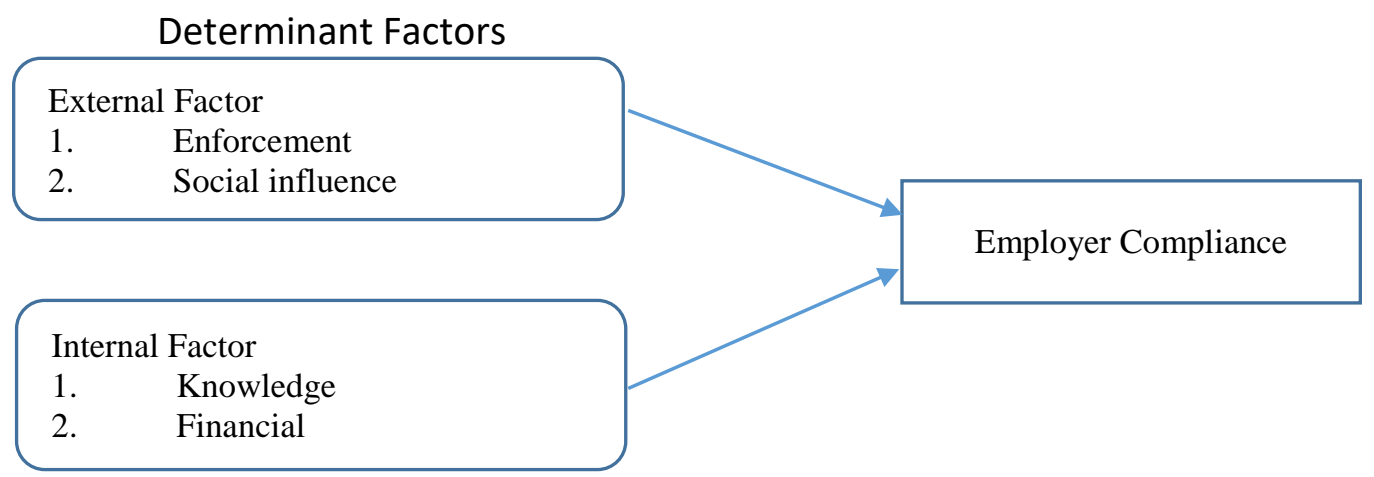

Figure 2: Conceptual Framework on Factors Influencing Employers' Compliance with Labour Standards

\section{Implications to Human Resource Development}

This study has major implications for the Human Resource Development (HRD). An organization are subject to a law and regulation in a diverse area and also related to the HRD aspects. In HRD, the area is not limited to the training, career planning, performance appraisal etc., other than that, it facilitates an organization environment which the people come first. To perform the successful HRD process, a good practice of labour standards must be accomplished first. A compliance of labour standards by an employer will keep a better environment within the organization. An employee who works with the compliance organization will feel safer, secure and encourage them to perform their duty as they know their welfare being protected and taking care. They are more likely to remain at an organization, rather than seeking employment elsewhere. Therefore, HRD related-program in the organization is easier to implement with full participation from the employee.

On the other hand, HRD process is one of the most significant activity that expected by an employee in order to improve themselves. Knowledge of the labour standards also one aspect of the HRD. Besides, an improvement in knowledge about organization process, product, and skill, an employee also must be educated with the basic knowledge about their right and responsibility as they are part of the organization. As a result, an employee is much easier accepting any changing in the organization as long as they know that their rights and welfare are protected. 
Besides, it is believable that when employees judge the organization to be fair and supportive especially in human resource practices such as adequacy of pay, benefits, a frequency of promotional opportunities and good supervision, positive feelings of well-being will be created, which is increasing their motivation and loyalty to the organization. Motivated employees tend to be persistent, creative and productive, turning out high quality work that they willingly undertake, demonstrate more innovative problem-solving and drive more impact (Ganta, 2014). Every employee has different ways to become motivated. Employers need to get to know their employees very well and use different tactics to motivate each of them based on their personal wants and needs. Therefore, it is important for an organization to create an environment that inspires and supports strong employee motivation.

\section{Contribution of the Study}

This paper has analyse the factors that play a role in compliance behaviour of labour standards which is the enforcement by government, knowledge, social influence and financial factor. For academics, a very few paper explaining on compliance of labour standard in Malaysia before, most of paper that determine the factors that influence labour standards compliance are from foreign country (Almeida \& Poole, 2017; Almeida \& Ronconi, 2016; Harwood, 2014; Islam \& Rahman, 2015; Ni \& Zhu, 2018; Piore \& Skinner, 2015; Sjogren \& Syrja, 2015; Viollaz, 2018; Vosko et al., 2016).

Meanwhile, this study filling the gaps occurring on labor standards compliance conceptual framework while previous research has focus the construct more on other fields such as tax compliance (Al et al., 2014; Fauziati et al., 2016; Musimenta, Nkundabanyanga, Muhwezi, Akankunda, \& Nalukenge, 2017), occupational safety compliance (Ghazali, N. \& Yaman, S. K. \& Hairuddin, 2014; Weissbrodt \& Giauque, 2017), compliance in data privacy (O'Neill, 2014) or compliance law in general (Voermans, 2014).

Furthermore, the findings of this study also will benefit the policy makers to address labor standards compliance issue more effectively. This study will aid to the government to strategize enforcement activity and program to encourage employer towards labor standards practices, restructuring operation and policy made on labor standards approach and compliance in the future. It helps the government and agency involved to narrow down and focus only on the factors that have more influence towards labour standards compliance and understanding the compliance trends of employers in the future. Besides, this paper is also benefits employers to understand the importance of law compliance as its might the factors that lead to employee motivation, company stability and productivity.

\section{Conclusion}

Based on the finding, it is lead to a conclusion about what factor have more influence towards labour standards compliance and make a recommendation for future research. It is obvious that external and internal factor both are important to pursue employer towards compliance action. Both factors play a role and have a strong influence on the employer in a different way to encourage an employer to obey the rules and regulation. Another conclusion was drawn from this conceptual paper is some variable have more influence than another variable. Enforcement by the government seems to give more influence to the companies towards a labour standards compliance compared to the social influence, knowledge and 
financial factor. A repetition inspection will force an employer to give more attention to their labour standards practice and their obligation towards employee welfare and protection. The employer feels afraid of being caught while inspection and have to facing court action caused not complying with labour standards.

The finding of this paper will assist the researcher indirectly in understanding the subject from a different perspective and future research should be conducted to test empirically which factor exert significant influence on employer compliance.

\section{Corresponding Author}

Siti Noormi Alias is a senior lecture at the Faculty of Educational Studies, Universiti Putra Malaysia, 43400 UPM Serdang, Selangor Darul Ehsan, Malaysia. E-mail: sitinoormi@upm.edu.my 
INTERNATIONAL JOURNAL OF ACADEMIC RESEARCH IN BUSINESS AND SOCIAL SCIENCES

Vol. 9, No. 10, October, 2019, E-ISSN: 2222-6990 @ 2019 HRMARS

\section{References}

Al, R., Saad, J., \& Haniffa, R. (2014). Determinants of zakah (Islamic tax) compliance behavior. Journal of Islamic Accounting and Business Research, 5(2), 158-181.

Almeida, R. K., \& Poole, J. P. (2017). Trade and labor reallocation with heterogeneous enforcement of labor regulations. Journal of Development Economics, 126(January), 154166.

Almeida, R., \& Ronconi, L. (2016). Labor Inspections in the Developing World: Stylized Facts from the Enterprise Survey. Industrial Relations, 55(3), 468-489.

Artuso, M., \& McLarney, C. (2015). A Race to the Top: Should Labour Standards be Included in Trade Agreements? Vikalpa, 40(1), 1-14.

Asselt, E. van, Osinga, S., \& Bremmers, H. (2016). Simulating compliance behaviour for effective inspection strategies using agent based modelling. British Food Journal, 118(4), 809-823.

Chakraborty, A., Singh, M. P., \& Roy, M. (2017). A study of goal frames shaping proenvironmental behaviour in university students. International Journal of Sustainability in Higher Education, 18(7), 1291-1310.

Cronin, P., Ryan, F., \& Coughlan, M. (2008). Undertaking a literature review : a step-by-step approach, 17(1), 38-43.

Etienne, J. (2011). Compliance Theory : A Goal Framing Approach. Law \& Policy, 33(3).

Fauziati, P., Minovia, A. F., Muslim, R. Y., \& R. Nasrah. (2016). The Impact of Tax Knowledge on Tax Compliance Case Study in Kota Padang , Indonesia. Journal of Advanced Research in Business and Management Studies, 2(1), 22-30.

Fisk, C., \& Rutter, J. (2015). Labor Protest Under the New First Amendment. Berkeley Journal of Employment \& Labor Law, 36(2), 277-329.

Foldspang, L., Mark, M., Rants, L. L., Hjorth, L. R., Langholz-Carstensen, C., Poulsen, O. M., ... Aasnæss, S. (2014). Working environment and productivity. Copenhagen: Nordic Council of Ministers.

Francesco, P., Oppenheimer, W., Donnelly, \& Ginsburg, T. (2015). Comparative labor law. (F. Parisi, O. Wolff, Donnelly, \& T. Ginsburg, Eds.). Cheltenham UK, Northampton MA USA: Edward Elgar Publishing.

Funke, J. (2017). How Much Knowledge Is Necessary for Action ? In Knowledge and space (Vol. 9, pp. 99-111). Switzerland: Springer International Publishing AG.

Galander, A., Walgenbach, P., \& Rost, K. (2015). A social norm perspective on corporate governance soft law. Corporate Governance, 15(1), 31-51.

Ganta, V. C. (2014). Motivation in the workplace to improve the employee performance. International Journal of Engineering Technology, Management and Applied Sciences, 2(6), 221-230.

Ghazali, N. \& Yaman, S. K. \& Hairuddin, M. (2014). Contractors' compliance on Occupational Safety and Health ( OSH ) policies in Malaysia's construction industry. Faculty of Civil and Environmental Engineering, (10-11 November), 2-3.

Gonzalez, D. (2015). Managing Online Risk. Butterworth-Heinemann (1st editio). Oxford UK: Butterworth-Heinemann.

Harwood, R. (2014). 'The dying of the light': the impact of the spending cuts, and cuts to 
INTERNATIONAL JOURNAL OF ACADEMIC RESEARCH IN BUSINESS AND SOCIAL SCIENCES Vol. 9, No. 10, October, 2019, E-ISSN: 2222-6990 @ 2019 HRMARS

employment law protections, on disability adjustments in British local authorities. Disability and Society, 29(10), 1511-1523.

Hwang, I., Kim, D., Kim, T., \& Kim, S. (2017). Why not comply with information security? An empirical approach for the causes of non-compliance. Online Information Review, 41(1), 218.

International Labour Organization. (2016). Non-standard employment around the world: Understanding challenges, shaping prospects. Geneva: Document and Publications Production, Printing and Distribution Branch.

Islam, M. S., \& Rahman, M. (2015). Promoting Bangladesh Labor Law to Managing Human Resources in Enterprises- Perspectives \& Challenges. International Journal of Advances in Management and Economics, 4(6), 114-123.

Kalis, A., Kaiser, S., \& Mojzisch, A. (2013). Why we should talk about option generation in decision-making research. Theoretical and Philosophical Psychology, 4(August), 1-8.

Kim, S. S., \& Kim, Y. J. (2017). The effect of compliance knowledge and compliance support systems on information security compliance behavior. Journal of Knowledge Management, 21(4), 986-1010.

Kono, P. M., \& Barnes, B. (2010). The role of finance in the strategic-planning and decisionmaking process. Graziadio Business Report, 13(1), 1-9.

Kristen, E., Banuelos, B., \& Urban, D. (2015). Workplace Violence and Harassment of Low-Wage Workers Low-Wage Workers. Berkeley Journal of Employment \& Labor Law, 36(1), 169213.

Lam, C. K., \& Goo, S. H. (2015). The issue of enforcement in Chinese corporate governance. Journal of Financial Crime, 22(4), 468-475.

Lindenberg, S., \& Steg, L. (2007). Normative, Gain and Hedonic Goal Frames Guiding Environmental Behavior. Journal of Social Issues, 63(1), 117-137.

Lindenberg, S., \& Steg, L. (2013). Goal-framing Theory and Norm-Guided Environmental Behavior. In Encouraging Sustainable Behavior (pp. 37-54). New York: Psychology Press.

Locke, R. M., \& Samel, H. (2018). Beyond the Workplace : Upstream Business Practices and Labor Standards in the Global Electronics Industry. Studies in Comparative International Development, 53(1), 1-24.

Murphy, K., Bradford, B., \& Jackson, J. (2016). Motivating Compliance Behavior Among Offenders: Procedural Justice or Deterrence? Criminal Justice and Behavior, 43(1), 102118.

Musimenta, D., Nkundabanyanga, S. K., Muhwezi, M., Akankunda, B., \& Nalukenge, I. (2017). Tax compliance of small and medium enterprises: a developing country perspective. Journal of Financial Regulation and Compliance, 25(2), 149-175.

Nakyeyune, G. K., Tauringana, V., Ntayi, J. M., \& Nkundabanyanga, S. K. (2016). Public finance regulatory compliance among public secondary schools. International Journal of Social Economics, 43(11), 1135-1155.

Ng, K. Y., \& Said, R. (2015). The role of labour standards in shaping migration: The Asean perspectives. Jurnal Ekonomi Malaysia, 49(2), 3-15.

$\mathrm{Ni}, \mathrm{X}$., \& Zhu, W. (2018). The bright side of labor protection in emerging markets: The case of 
INTERNATIONAL JOURNAL OF ACADEMIC RESEARCH IN BUSINESS AND SOCIAL SCIENCES Vol. 9, No. 10, October, 2019, E-ISSN: 2222-6990 @ 2019 HRMARS

firm transparency. Pacific Basin Finance Journal, 50(C), 126-143.

Nielsen, V. L., \& Parker, C. (2012). Mixed Motives : Economic, Social , and Normative Motivations in Business Compliance. Law \& Policy, 34(4), 429-462.

Nurunnabi, M. (2017). Tax evasion and religiosity in the Muslim world : the significance of Shariah regulation. Quality \& Quantity, 52(1), 371-394.

O'Neill, A. (2014). An action framework for compliance and governance. Clinical Governance: An International Journal, 19(4), 342-359.

Pandey, C., \& Diwan, H. (2018). Integrated approach for managing fertilizer intensification linked environmental issues. Management of Environmental Quality: An International Journal, 29(2), 324-327.

Peterson, E. A. (2013). Compliance and ethics programs: Competitive advantage through the law. Journal of Management and Governance, 17(4), 1027-1045.

Piore, M. J., \& Skinner, D. W. (2015). Labor Standards and Worker Organization Strategy. Roosevelt Institute. New York: Brief Publication.

Poudel, R. L. (2017). Tax Knowledge Among University Teachers In Pokhara. The Journal of Nepalese Business Studies, X(1), 69-77.

Qian, S. (2014). How do individual factors influence moral decision making in Entrepreneurship? The role of self-construal, temporal construal and moral identity. University of Louisville.

Raziq, A., \& Maulabakhsh, R. (2015). Impact of Working Environment on Job Satisfaction. Procedia Economics and Finance, 23(October 2014), 717-725.

Rhodes, C., \& Wray-Bliss, E. (2013). The ethical difference of Organization. Organization, 20(1), 39-50.

Rorie, M. (2015). An integrated theory of corporate environmental compliance and overcompliance. Crime Law Social Change, 64(2-3), 65-101.

Schwartz, M. S. (2016). Ethical Decision-Making Theory: An Integrated Approach. Journal of Business Ethics, 139(4), 755-776.

Shakeel, N. (2015). Factors Influencing Employee Retention : An Integrated Perspective. Journal of Resources Development and Management, 6, 32-50.

Shilpa, P. (2011). Research into employers ' attitudes and behaviour towards compliance with UK National Minimum Wage ( NMW ) legislation. Employment Relation Research Series. London: Department for Business, Innovation \& Skills.

Sjogrén, H., \& Syrja, P. (2015). Regulation compliance in small Finnish companies. International Journal of Law and Management, 57(6), 649-661.

Su, J. A. (2016). Enforcing Labor Laws : Wage Theft, the Myth of Neutrality, and Agency Transformation. Berkeley Journal of Employment \& Labor Law, 37(1), 143-156.

Tomlins, C. (2013). The State, the Unions, and the critical synthesis in labor law history : a 25year retrospect. Labor History, 54(2), 208-221.

Viollaz, M. (2018). Enforcement of labor market regulations: heterogeneous compliance and adjustment across gender. IZA Journal of Labor Policy, 7(2).

Voermans, W. (2014). Motive based enforcement. In Regulatory Reforms; Implementation and Compliance (pp. 41-61).

Vosko, L. F., Gruncy, J., Tucker, E., M.Noack, A., Hall, A., P.Thomas, M., Akkaymak, G. (2016). 
Improving Employment Standards and their Enforcement in Ontario.

Weil, D. (1996). If OSHA is So Bad, Why is Compliance So Good? The RAND Journal of Economics, 27(3), 618.

Weil, D. (2011). Enforcing Labour Standards in Fissured Workplaces: The US Experience. The Economic and Labour Relations Review, 22(2), 33-54.

Weissbrodt, R., \& Giauque, D. (2017). Labour inspections and the prevention of psychosocial risks at work: A realist synthesis. Safety Science, 100, 110-124.

Wildgruber, S. (2013). The Core Labour Standards of the International Labour Organization -Can Contemporary Compliance Theories Explain the Behaviour of States Towards the Norms?

Yeoh, P. (2014). Whistleblowing: motivations, corporate self-regulation, and the law. International Journal of Law and Management, 56(6), 459-474. 